\title{
EVALUATION OF PERFORMANCE OF DIFFERENT ALUMINIUM-BASED COAGULANTS AND AIDS IN RIVER WATER CLARIFICATION
}

\author{
S. MUKHERJEE ${ }^{1,3}$, A.K. BHATTACHARYA ${ }^{2} \&$ S.N. MANDAL ${ }^{3}$ \\ ${ }^{1}$ Ramakrishna Mission Shilpapitha, Belgharia, Kolkata, India. \\ ${ }^{2}$ Tellabs India Private Limited, Mumbai, India. \\ ${ }^{3}$ National Institute of Technical Teachers' Training and Research, Kolkata, India.
}

\begin{abstract}
Coagulation and flocculation is one of the most effective, economic and convenient method for raw water clarification. In recent times, different hydrolysing coagulants, particularly aluminium-based ones are in wide use. In the present study, different aluminium-based salts, polymer and coagulant aid were used to observe their effectiveness as well as side effects, if any. Turbidity was the prime criterion for clarification of the raw water; however, the potentially hazardous residual aluminium was also given due importance.

Poly-aluminium chloride ( $\mathrm{PACl}$ ) enhanced the performance of the potash alum when used in tandem, whereas bentonite powder used as coagulant aid proved ineffective in improving the performance of the potash alum with respect to the removal of the turbidity. PACl when used alone or in tandem with potash alum showed character significantly different from aluminium-based salts only, with respect to the criterion of residual aluminium. Keywords: Coagulation, flocculation, hydrolysing coagulants, residual aluminium, river water, turbidity
\end{abstract}

\section{INTRODUCTION}

Raw surface water usually contains colloidal particles. The surface charges on these particles prevent them from settling down due to gravitational forces and keep them in suspension [1, 2]. Coagulation-flocculation is a very convenient process to destabilise these charged particles making them agglomerate and settle down.

In the present study, different aluminium-based coagulants and coagulant aid were tried and assessed for their usefulness in removing different parameters particularly turbidity to make the water potable [3-8]. After effect particularly in terms of residual aluminium were determined to foresee any hazardous impact on human beings. The residual aluminium may cause Alzheimer's disease or other related problems as reported by Pan et al. [9], Divakaran and Pillai [10] and Schintu et al. [11]. The coagulants and coagulant aids tried for this study were aluminium sulphate $\left[\mathrm{Al}_{2}\left(\mathrm{SO}_{4}\right)_{3}\right.$, $\left.16 \mathrm{H}_{2} \mathrm{O}\right]$, potassium aluminium sulphate $\left[\mathrm{KAl}\left(\mathrm{SO}_{4}\right)_{2}, 12 \mathrm{H}_{2} \mathrm{O}\right]$ or potash alum, poly-aluminium chloride $(\mathrm{PACl})$, potash alum with $\mathrm{PACl}$ and potash alum with bentonite powder.

\section{MATERIALS AND METHODS}

\subsection{Sampling}

The grab samples of raw river water were taken manually from the Ahiritola Ghat, in Kolkata, West Bengal, India from the river Ganga. The samples were taken every alternate day over a period of 3 months during low and medium turbidity period at the time of the onset of high tide. The samples were collected from below the surface avoiding floating matters at a distance of about $15 \mathrm{~m}$ from the bank of the river. Samples were collected in polytetrafluoroethylene (PTFE) containers. The samples were properly labelled, sealed and tested as soon as possible after collection on the same day. The sample collection, transport and preservation (where needed) were done 
in accordance to section $1060 \mathrm{~B}$ and $1060 \mathrm{C}$ of Standard Methods for the Examination of Water and Wastewater [12]. The samples were treated with aluminium sulphate, potash alum with and without performance enhancing substance (bentonite powder) and $\mathrm{PACl}$ to obtain optimum dosages of coagulants and their effects on different parameters, particularly in the low and medium turbidity river water samples [13-18]. The graphs have been generated using the mean values for all the parameters.

\subsection{Experimental procedures}

For each sample, the following analyses were carried out:

- Turbidity was measured by Nephelometric method based on a comparison of the intensity of light scattered by the sample under defined conditions with the intensity of light scattered by a standard reference suspension under the same conditions.

Apparatus used - 2100 N TURBIDIMETER (HACH Co., USA).

- Measurement of $\mathrm{pH}$ is one of the most important and frequently used tests in water chemistry and particularly in coagulation. The $\mathrm{pH}$ measurements were done by $\mathrm{pH}$ meter following electrometric method. Apparatus used - WTW (inoLab pH 730, USA).

- Total alkalinity was measured by titrimetric method.

- Total dissolved solid (TDS) was determined by electrical conductance using dual-mode conductivity and TDS meter (by WTW, inoLab cond 720, USA). The results were cross examined by conventional drying at $180^{\circ} \mathrm{C}$ and found in close conformity with the result measured by the TDS meter.

- Aluminium was measured through a UV-VIS Spectrophotometer at wavelength $(\lambda) 535 \mathrm{~nm}$ following Eriochrome Cyanine R method. Apparatus used - DR5000 UV-VIS Spectrophotometer (HACH Co., USA).

- Iron was measured through a UV-VIS Spectrophotometer at wavelength ( $\lambda$ ) $510 \mathrm{~nm}$ following phenanthroline method. Apparatus used - DR5000 UV-VIS Spectrophotometer (HACH Co., USA).

- Total hardness was measured by EDTA titrimetric method.

- As the sludge was in dilute form, the sludge volumes were measured volumetrically in terms of settleable solids with the help of Imhoff Cones - BOROSIL, India.

The Standard Practice for Coagulation-flocculation Jar Test of Water, ASTM D 2035 [19], was first adopted in 1980 and re-approved in 1999. Since coagulant interactions are very complex, laboratory studies are needed to determine the suitable coagulant, optimal dosage, duration and intensity of mixing and flocculation [20-26]. The coagulation and flocculation experiments were carried out by Jar test (by Programmable Phipps and Birds Jar Test Apparatus, Richmond, VA USA Model $\mathrm{PB} 900)$. The coagulants chosen were aluminium sulphate $\left[\mathrm{Al}_{2}\left(\mathrm{SO}_{4}\right)_{3}, 16 \mathrm{H}_{2} \mathrm{O}\right]$, potash alum $\left[\mathrm{KAl}\left(\mathrm{SO}_{4}\right)_{2}, 12 \mathrm{H}_{2} \mathrm{O}\right]$ (supplied by Merck Specialities, India Private Limited). Bentonite powder $\left[\mathrm{Al}_{2} \mathrm{O}_{3}, 4 \mathrm{SiO}_{2}, \mathrm{H}_{2} \mathrm{O}\right]$ supplied by Merck Specialities, India Private Limited, was used as a coagulant aid to potash alum. $\mathrm{PACl}$, a pre-polymerised coagulant, is increasingly used in recent years because of its advantages over simple salts. It is effective over a wide $\mathrm{pH}$ range and shows low sensitivity to temperature. It reduces sludge quantities and improves sludge dewaterability [27-29]. In this study, $\mathrm{PACl}$ (commercial grade - supplied by Grasim, India) was used in conjunction with potash alum to reduce the quantity of potash alum and/or to improve the treated water quality. It was also used independently as a coagulant. 
Characteristics of $\mathrm{PACl}$

\begin{tabular}{ll}
\hline Characteristics & Value \\
\hline Appearance & Pale yellow powder \\
Bulk density & $0.75 \pm 0.10$ \\
$\mathrm{pH}$ of $1 \%$ solution $(\mathrm{w} / \mathrm{v})$ & $3.5-5.0$ \\
$\mathrm{Al}_{2} \mathrm{O}_{3}$ & $30 \pm 1 \%$ \\
Sulphate & $\mathrm{Nil}$ \\
\hline
\end{tabular}

Table 1: Raw water characteristics.

\begin{tabular}{lrrrr}
\hline Parameter (unit) & Minimum & Maximum & Mean & Standard deviation \\
\hline $\mathrm{pH}$ & 7.391 & 8.532 & 8.023 & 0.283 \\
Turbidity (NTU) & 30.1 & 159 & 82.1 & 32.65 \\
Total dissolved solid (TDS) (mg/L) & 102 & 210 & 156 & 29.4 \\
Total hardness (as $\left.\mathrm{CaCO}_{3,}, \mathrm{mg} / \mathrm{L}\right)$ & 78 & 165 & 115 & 27.3 \\
Total alkalinity (as $\left.\mathrm{CaCO}_{3,}, \mathrm{mg} / \mathrm{L}\right)$ & 98 & 191 & 140 & 31.9 \\
Total aluminium $\left(\mathrm{mg}_{\mathrm{L}} \mathrm{L}\right)$ & 0.000 & 0.021 & 0.009 & 0.006 \\
Total iron $(\mathrm{mg} / \mathrm{L})$ & 0.319 & 0.521 & 0.419 & 0.065 \\
\hline
\end{tabular}

Based on a series of studies, the following operating conditions were selected:

- Rapid mixing speed, $150 \mathrm{rpm}$.

- Rapid mixing time, 1 min.

- Flocculation speed, $25 \mathrm{rpm}$.

- Flocculation time, 20 min.

- Settling time, $30 \mathrm{~min}$.

The analytical methods were adopted from the Standard Methods for the Examination of Water and Wastewater [12].

The characteristics of the raw water are presented in Table 1.

\section{RESULTS AND DISCUSSION}

\subsection{Study of coagulants}

\subsubsection{Variation of $\mathrm{pH}$ in treated water}

Figures 1 and 2 show the variation of $\mathrm{pH}$ with aluminium sulphate, potash alum, $\mathrm{PACl}$ and potash alum with $\mathrm{PACl}$ as coagulants expressed in terms of concentration of aluminium. In all the four cases, $\mathrm{pH}$ decreased with the dosages of coagulants. However, the values of $\mathrm{pH}$ of the dosed solution were less than the initial $\mathrm{pH}$ (8.258) of raw water in the cases of aluminium sulphate and potash alum, whereas the $\mathrm{pH}$ increased for the starting dosages of $\mathrm{PACl}$ and potash alum with PACl. This may be due to the fact that aluminium sulphate and potash alum are acidic salts; they reduced the $\mathrm{pH}$ 


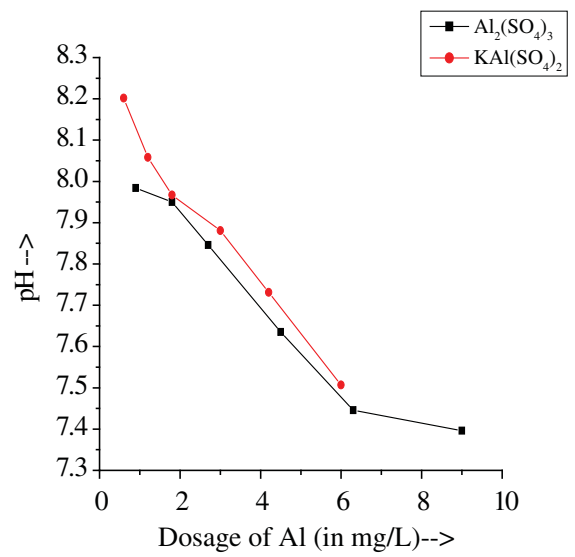

Figure 1: $\mathrm{pH}$ vs. dosages of $\mathrm{Al}_{2}\left(\mathrm{SO}_{4}\right)_{3}, 16 \mathrm{H}_{2} \mathrm{O} / \mathrm{KAl}\left(\mathrm{SO}_{4}\right)_{2}, 12 \mathrm{H}_{2} \mathrm{O}$ in terms of aluminium.

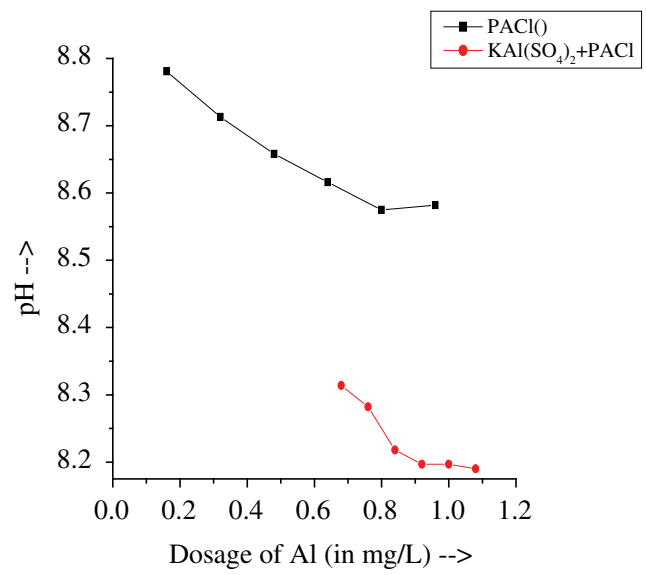

Figure 2: $\mathrm{pH}$ vs. dosages of $\mathrm{PACl} / \mathrm{KAl}\left(\mathrm{SO}_{4}\right)_{2}, 12 \mathrm{H}_{2} \mathrm{O}$ and $\mathrm{PACl}$ in terms of aluminium.

of the treated water. On the other hand, the predominant hydrolysis product of $\mathrm{PACl}$ having low aluminium (Al) concentration and slow rate of dissociation at $\mathrm{pH}$ above 8 is aluminate AWWA Water Quality \& Treatment [30]. This aluminate on further reaction with water may liberate some hydroxyl $\left(\mathrm{OH}^{-}\right)$ions, which may be considered as a probable cause of enhanced $\mathrm{pH}$ value. With higher dosages of $\mathrm{PACl}$, net $\mathrm{pH}$ reduced. This may be because due to the increase in $\mathrm{Al}$ concentration, there was a corresponding decrease in aluminate and subsequent hydroxyl ion concentration. The $\mathrm{pH}$ of the $\mathrm{PACl}$ solution with which dosing was done, being less than 7 , the increases in added $\mathrm{PACl}$ quantity also reduced the net $\mathrm{pH}$ of the solution.

\subsubsection{Variation of turbidity in treated water}

Figures 3 and 4 show the percentage reduction of turbidity with aluminium sulphate, potash alum, $\mathrm{PACl}$ and potash alum with PACl. In all the four cases, the percentage reduction of turbidity increased with the dosages of the coagulants. However, for aluminium sulphate and potash alum 


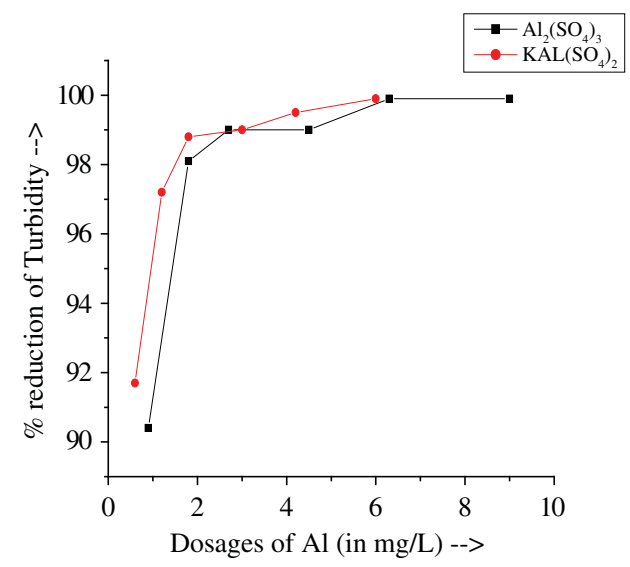

Figure 3: Percentage reduction of turbidity vs. dosages of $\mathrm{Al}_{2}\left(\mathrm{SO}_{4}\right)_{3}, 16 \mathrm{H}_{2} \mathrm{O} / \mathrm{KAl}\left(\mathrm{SO}_{4}\right)_{2}, 12 \mathrm{H}_{2} \mathrm{O}$ in terms of aluminium.

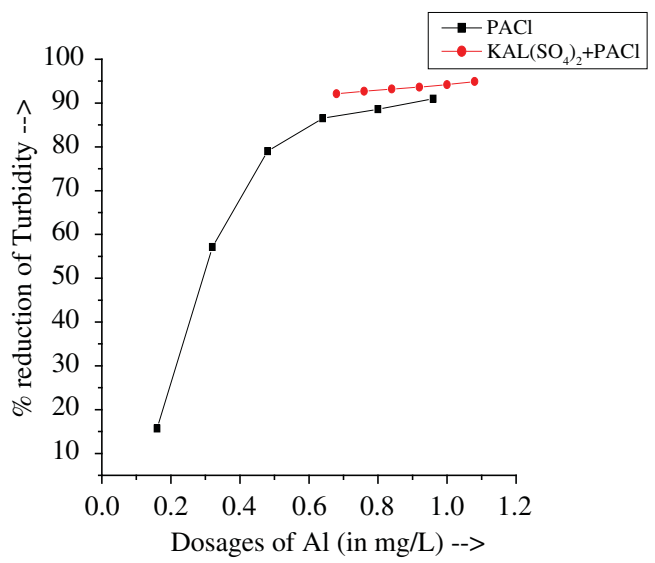

Figure 4: Percentage reduction of turbidity vs. dosages of $\mathrm{PACl} / \mathrm{KAl}\left(\mathrm{SO}_{4}\right)_{2}, 12 \mathrm{H}_{2} \mathrm{O}$ and $\mathrm{PACl}$ in terms of aluminium.

the increase was rapid in lower dosages up to $1.8 \mathrm{mg} / \mathrm{L}$ of $\mathrm{Al}$ concentration and reached a saturation level, i.e. small changes occurred beyond $2.7 \mathrm{mg} / \mathrm{L}$ of $\mathrm{Al}$ concentration. In the case of $\mathrm{PACl}$, the increase was gradual for the whole study range up to $0.96 \mathrm{mg} / \mathrm{L}$ of $\mathrm{Al}$ concentration. For potash alum with $\mathrm{PACl}$, the values of percentage reduction of turbidity increased slowly after attaining an initial high value.

\subsubsection{Variation of sludge volume in treated water}

Figures 5 and 6 show the variation of sludge volume with aluminium sulphate, potash alum, PACl and potash alum with PACl used as coagulants. In all the four cases, the sludge volumes increased with increase in the amount of coagulants as expected from our understanding and general theoretical knowledge of coagulation-flocculation theory. However, the sludge volume (in $\mathrm{mL} / \mathrm{L}$ ) was considerably low in the case of $\mathrm{PACl}$ and potash alum with $\mathrm{PACl}$ compared with aluminium sulphate 


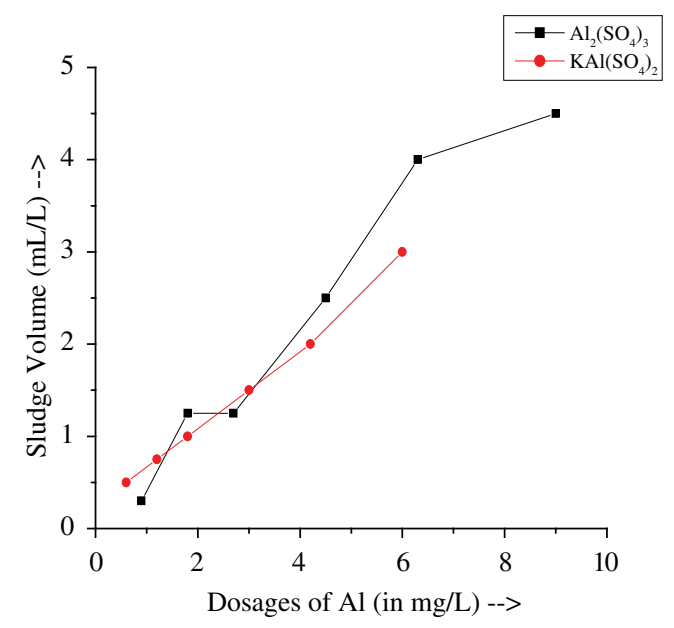

Figure 5: Sludge volume vs. dosages of $\mathrm{Al}_{2}\left(\mathrm{SO}_{4}\right)_{3}, 16 \mathrm{H}_{2} \mathrm{O} / \mathrm{KAl}\left(\mathrm{SO}_{4}\right)_{2}, 12 \mathrm{H}_{2} \mathrm{O}$ in terms of aluminium.

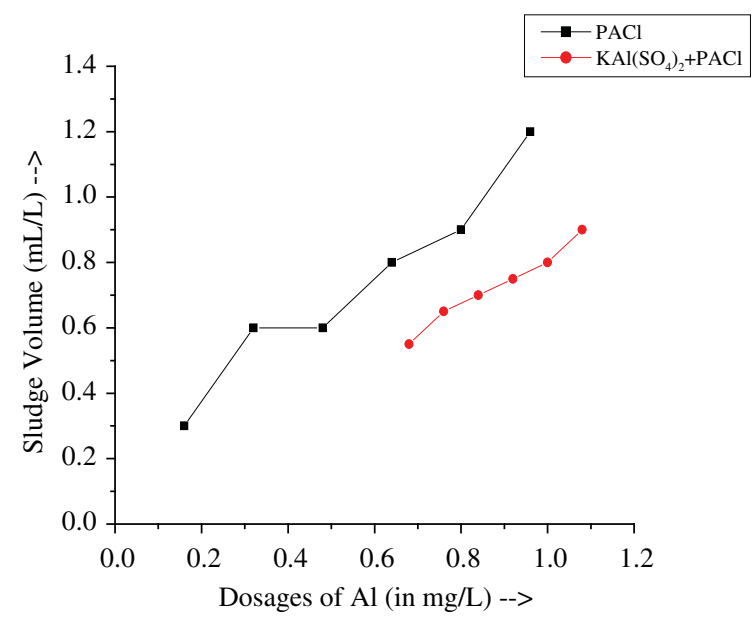

Figure 6: Sludge volume vs. dosages of $\mathrm{PACl} / \mathrm{KAl}\left(\mathrm{SO}_{4}\right)_{2}, 12 \mathrm{H}_{2} \mathrm{O}$ and $\mathrm{PACl}$ in terms of aluminium.

or potash alum alone. This lower sludge volume probably resulted from significantly lower amounts of $\mathrm{Al}$ being added to the solution.

3.1.4 Variation of residual aluminium in treated water

From Figs 7 and 8, the amount of residual aluminium in treated water after treatment with aluminium sulphate, potash alum, $\mathrm{PACl}$ and potash alum with $\mathrm{PACl}$ may be observed. In the case of aluminium sulphate and potash alum, the residual aluminium quantities decreased with increase in the amount of coagulants, whereas for $\mathrm{PACl}$ the residual aluminium quantities increased with increase in the dosages. For potash alum with $\mathrm{PACl}$, initially the residual Al quantities decreased as in the case of potash alum alone, but the trend reversed with increase in $\mathrm{PACl}$ at the end portion. 


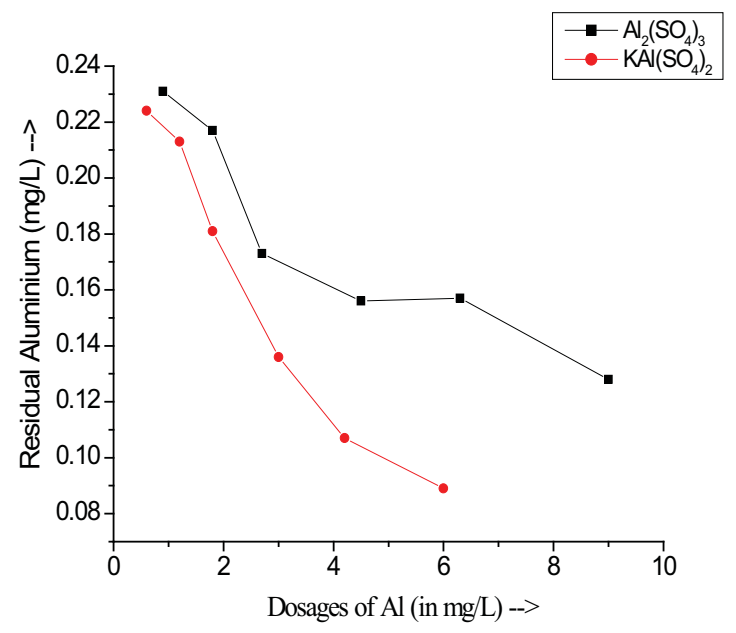

Figure 7: Residual aluminium vs. dosages of $\mathrm{Al}_{2}\left(\mathrm{SO}_{4}\right)_{3}, 16 \mathrm{H}_{2} \mathrm{O} / \mathrm{KAl}\left(\mathrm{SO}_{4}\right)_{2}, 12 \mathrm{H}_{2} \mathrm{O}$ in terms of aluminium.

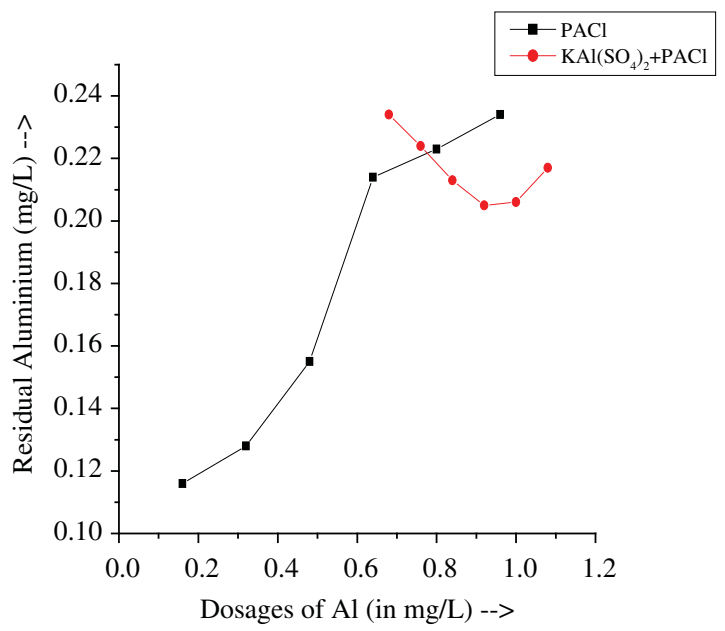

Figure 8: Residual aluminium vs. dosages of $\mathrm{PACl} / \mathrm{KAl}\left(\mathrm{SO}_{4}\right)_{2}, 12 \mathrm{H}_{2} \mathrm{O}$ and $\mathrm{PACl}$ in terms of aluminium.

This may be due to the fact that the distribution of the $\mathrm{Al}(\mathrm{III})$ species at equilibrium depends on the $\mathrm{pH}$ and the total $\mathrm{Al}$ concentration. Accordingly in the cases of aluminium sulphate and potash alum, as the quantities of aluminium increased the major hydrolysis product formed was $\mathrm{Al}(\mathrm{OH})_{3}$ and it readily precipitated causing sweep flocculation, reducing the quantity of available aluminium in the solution. However, in the case of $\mathrm{PACl}$, as the quantities of coagulant applied were much less compared with the other coagulants and the resulting $\mathrm{pH}$ of the solutions were higher, the soluble portions of the aluminium added increased, increasing the amount of residual aluminium. 


\subsection{Study of coagulant aids}

Bentonite powder was tried as coagulant aid in conjunction to potash alum and the result is compared vis-à-vis potash alum alone. As low and medium turbidity river waters were investigated, bentonite powder was added to increase particle collisions and observe its effect on floc growth and other parameters.

\subsubsection{Variation of $\mathrm{pH}$ in treated water}

From Figs 9 and 10, it is observed that in the case of potash alum only, the $\mathrm{pH}$ gradually reduced. Whereas when higher dosages of bentonite were added to potash alum, the $\mathrm{pH}$ value decreased but did not follow a regular trend. For both the cases, the initial $\mathrm{pH}$ value was 8.258.

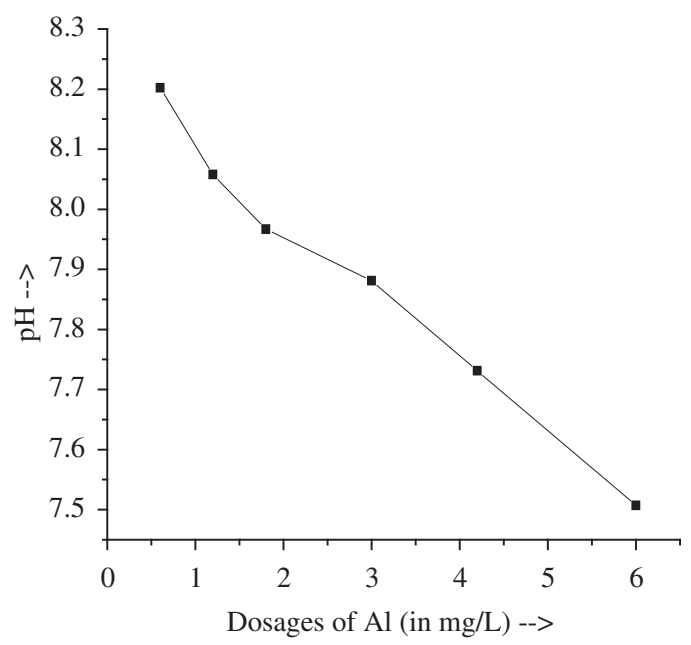

Figure 9: $\mathrm{pH}$ vs. dosages of $\mathrm{KAl}\left(\mathrm{SO}_{4}\right)_{2}, 12 \mathrm{H}_{2} \mathrm{O}$ in terms of aluminium.

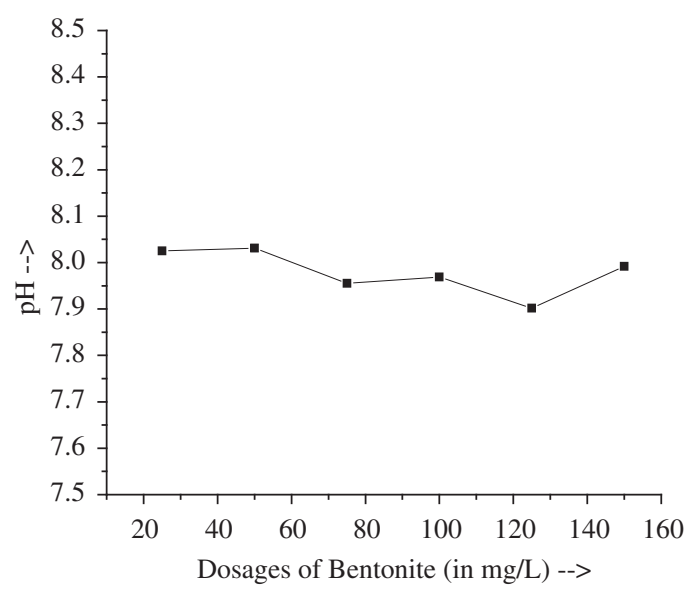

Figure 10: $\mathrm{pH}$ vs. dosages of bentonite powder (with $1.2 \mathrm{mg} / \mathrm{L} \mathrm{KAl}\left(\mathrm{SO}_{4}\right)_{2}, 12 \mathrm{H}_{2} \mathrm{O}$ in terms of aluminium). 


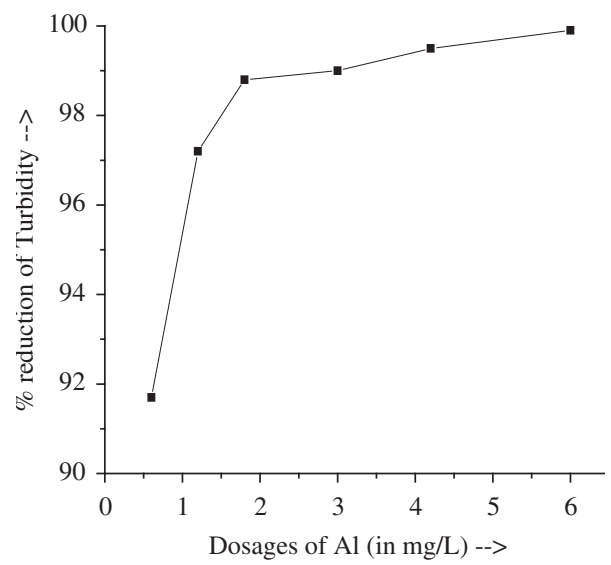

Figure 11: Percentage reduction of turbidity vs. dosages of $\mathrm{KAl}\left(\mathrm{SO}_{4}\right)_{2}, 12 \mathrm{H}_{2} \mathrm{O}$ in terms of aluminium.

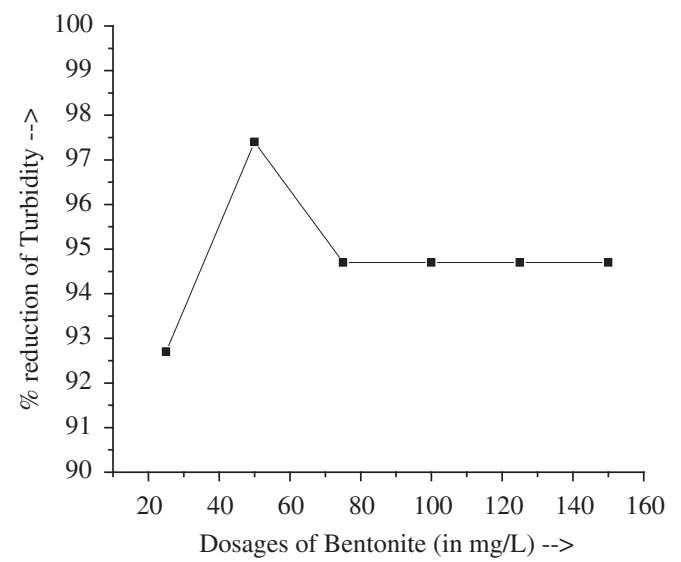

Figure 12: Percentage reduction of turbidity vs. dosages of bentonite powder (with $1.2 \mathrm{mg} / \mathrm{L}$ $\mathrm{KAl}\left(\mathrm{SO}_{4}\right)_{2}, 12 \mathrm{H}_{2} \mathrm{O}$ in terms of aluminium).

\subsubsection{Variation of turbidity in treated water}

Figures 11 and 12 show the variation of turbidity removal with increase in dosages of potash alum and potash alum with bentonite powder. Figure 11 shows that the percentage reduction values increased with increase in dosages of potash alum. For bentonite powder with a fixed dosage of potash alum, the percentage reduction in turbidity remained static after an initial increase at the dosage of $50 \mathrm{mg} / \mathrm{L}$ bentonite powder. The highest value of turbidity removal by bentonite powder with potash alum was almost same with that of potash alum alone at the dosage of $1.2 \mathrm{mg} / \mathrm{L}$ of Al concentration. This indicates inertness on the part of bentonite powder in turbidity removal of this river water, rather bentonite powder decreased the removal potential of potash alum used alone in this low and medium turbidity range.

\subsubsection{Variation of sludge volume in treated water}

Figures 13 and 14 compare the variation of sludge volume with increase in dosages of coagulant aid. For both potash alum and bentonite powder with potash alum, sludge volumes increased with 


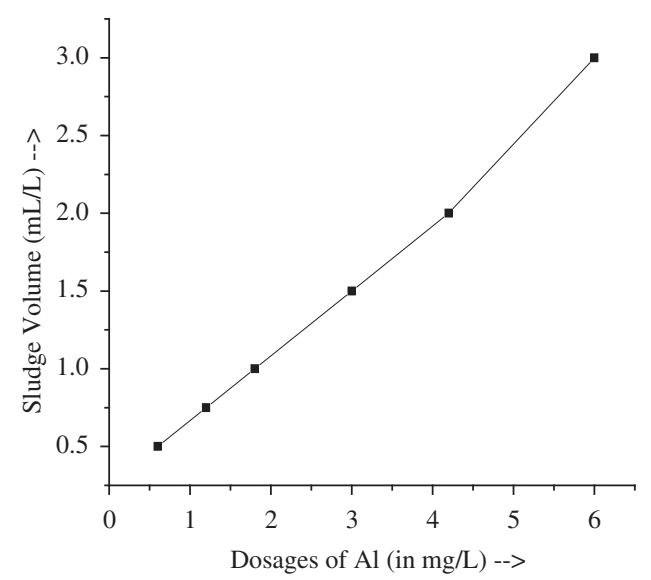

Figure 13: Sludge volume vs. dosages of $\mathrm{KAl}\left(\mathrm{SO}_{4}\right)_{2}, 12 \mathrm{H}_{2} \mathrm{O}$ in terms of aluminium.

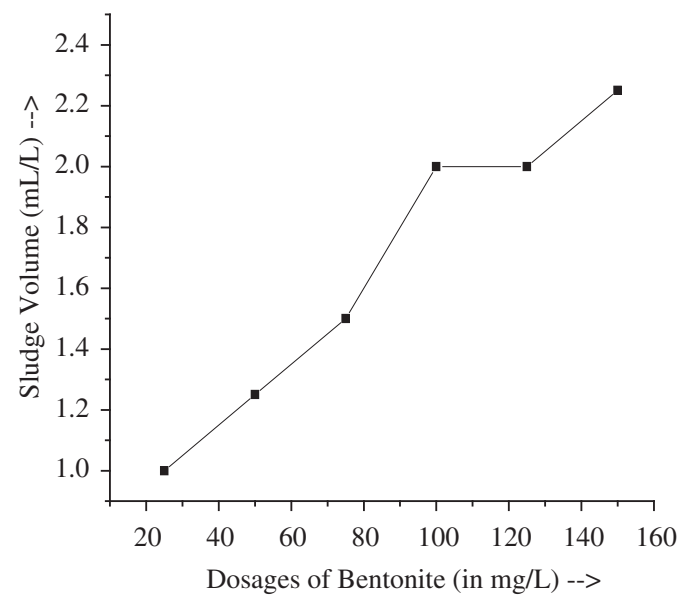

Figure 14: Sludge volume vs. dosages of bentonite powder (with $1.2 \mathrm{mg} / \mathrm{L} \mathrm{KAl}\left(\mathrm{SO}_{4}\right)_{2}, 12 \mathrm{H}_{2} \mathrm{O}$ in terms of aluminium).

increase in dosages as expected. Comparing sludge volumes of bentonite powder with potash alum to only potash alum of $1.2 \mathrm{mg} / \mathrm{L}$ of $\mathrm{Al}$ concentration dosage, it can be observed that bentonite added to the sludge volume without increasing turbidity removal efficiency.

\subsubsection{Variation of residual aluminium in treated water}

Figures 15 and 16 show the variation of residual aluminium with increase in dosages of potash alum and bentonite powder with fixed dosage $(1.2 \mathrm{mg} / \mathrm{L}$ of $\mathrm{Al})$ of potash alum. For bentonite powder with potash alum, the residual aluminium value decreased with increase in dosages initially; however, the trend reversed at the end. This may be due to the fact that initially the main coagulant, i.e. potash 


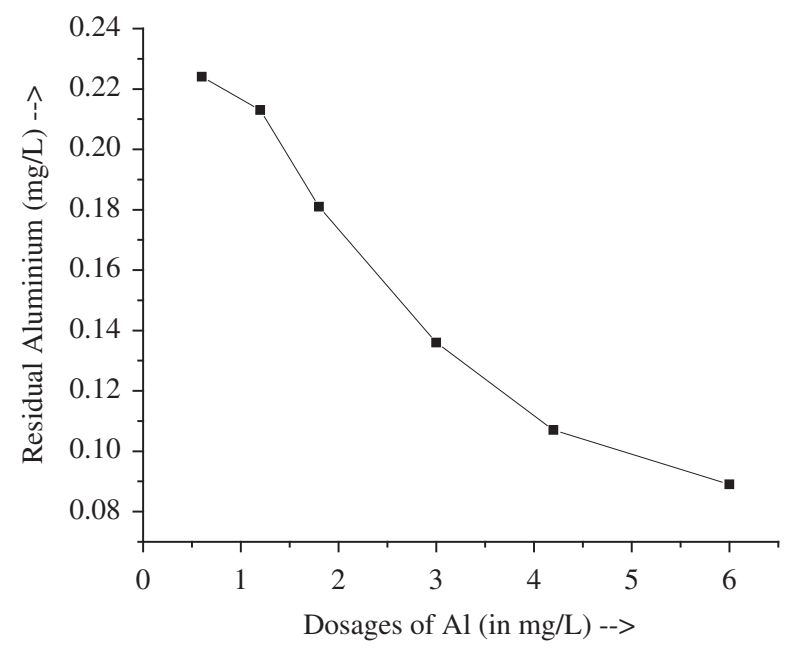

Figure 15: Residual aluminium vs. dosages of $\mathrm{KAl}\left(\mathrm{SO}_{4}\right)_{2}, 12 \mathrm{H}_{2} \mathrm{O}$ in terms of aluminium.

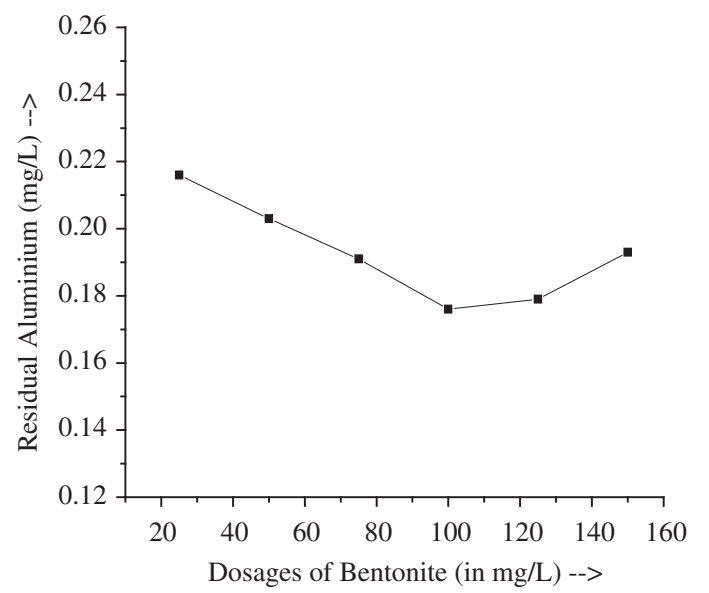

Figure 16: Residual aluminium vs. dosages of bentonite powder(with $1.2 \mathrm{mg} / \mathrm{L} \mathrm{KAl}\left(\mathrm{SO}_{4}\right)_{2}, 12 \mathrm{H}_{2} \mathrm{O}$ in terms of aluminium).

alum played the major part in turbidity removal by way of sweep flocculation; however, with increase in dosages of bentonite powder the soluble components of hydrolysis products increased thereby increasing the amount of residual aluminium.

\section{CONCLUSIONS}

The results and discussions show that hydrolysing metal salts (HMS), i.e. $\mathrm{Al}_{2}\left(\mathrm{SO}_{4}\right)_{3}, 16 \mathrm{H}_{2} \mathrm{O}$ and potash alum when used alone reduced the $\mathrm{pH}$ of the treated water right from the beginning. However, when $\mathrm{PACl}$ was added, initially the $\mathrm{pH}$ increased for small dosages. With increase in PACl volume, the dissociation pattern changed and $\mathrm{pH}$ got reduced. The trend was similar both when PACl was 
used alone or in conjunction with potash alum. Bentonite powder reduced the $\mathrm{pH}$ of the solution to a very small amount.

Turbidity reduction performances were good for both the HMS and also when PACl was used alone or with potash alum. For HMS alone, the desired turbidity was achieved within $1.8 \mathrm{mg} / \mathrm{L}$ of $\mathrm{Al}$ concentration. For $\mathrm{PACl}$ alone, the required dosage was $0.6 \mathrm{mg} / \mathrm{L}$ of $\mathrm{Al}$ concentration. For PACl with potash alum, the required dosages were $0.6 \mathrm{mg} / \mathrm{L} \mathrm{Al}$ concentration of potash alum and 0.08 $\mathrm{mg} / \mathrm{L}$ of $\mathrm{Al}$ concentration of $\mathrm{PACl}$. Bentonite powder was not very effective for turbidity reduction.

Sludge volumes were considerably lower when PACl was used compared with HMS alone. PACl with potash alum proved the most effective in terms of minimising the sludge volume. Bentonite powder with potash alum increased the sludge volume compared with potash alum alone.

For HMS, the residual aluminium quantity decreased with increasing dosages due to sweep flocculation. However, when PACl was added the residual aluminium quantity increased possibly due to different hydrolysis products in comparison with HMS. For bentonite powder with potash alum, initially the residual aluminium quantity decreased but beyond a certain concentration of bentonite powder it started increasing again.

\section{REFERENCES}

[1] Alaert, G. \& Van Haute, A., Coagulation and flocculation mechanism in diverse colloidal suspensions. Proceedings of Joint Seminar of S.V. ward S.E.D.E., pp. 45-74, 1981.

[2] Gregory, J., Stability and flocculation of colloidal particles. Effluents Water Journal, 17, pp. 515-521, 1977.

[3] Aboulhassan, M.A., Souabi, S., Yaacoubi, A. \& Baudu, M., Removal of surfactant from industrial wastewaters by coagulation flocculation process. International Journal of Environmental Science and Technology, 3(4), pp. 327-332, 2006. doi: http://dx.doi.org/10.1007/BF03325941

[4] Aguilar, M.I., Sáez, J., Lloréns, M., Soler, A., Ortuño, J.F., Meseguer, V. \& Fuentes, A., Improvement of coagulation-flocculation process using anionic polyacrylamide as coagulant aid. Chemosphere, 58, 47-56, 2005. doi: http://dx.doi.org/10.1016/j.chemosphere.2004.09.008

[5] Lerch, A., Panglisch, S., Buchta, P., Tomita, Y., Yonekawa, H., Hattori, K. \& Gimbel, R., Direct river water treatment using coagulation/ceramic membrane microfiltration. Desalination, 179, pp. 41-50, 2005.doi: http://dx.doi.org/10.1016/j.desal.2004.11.054

[6] Bolto, B.A., Dixon, D.R., Gray, S.R., Chee, H., Harbour, P.J., Ngoc, L. \& Ware, A., The use of soluble organic polymers in waste treatment. Water Science Technology, 34(9), pp. 117-124, 1996. doi: http://dx.doi.org/10.1016/S0273-1223(96)00794-9

[7] Dempsey, B., Removal of naturally occurring compounds by coagulation and sedimentation. Critical Reviews in Environmental Control, 14(4), pp. 311-331, 1984. doi: http://dx.doi. org/10.1080/10643388409381722

[8] Lin, L. Jr., Chin, C.-J.M., Huang, C., Pan, J.R., \& Wang, D., Coagulation behaviour of $\mathrm{Al}_{13}$ aggregates. Water Research, 42, pp. 4281-4290, 2008. doi: http://dx.doi.org/10.1016/j.watres.2008.07.028

[9] Pan, R.J., Huang, C., Chen, S. \& Chung, Y.C., Evaluation of a modified chitosan biopolymer for coagulation of colloidal particles. Colloids and Surfaces A: Physicochemical and Engineering Aspects, 147, pp. 359-364, 1999. doi: http://dx.doi.org/10.1016/S0927-7757(98)00588-3

[10] Divakaran, R. \& Pillai, V.N.S., Flocculation of kaolinite suspensions in water by chitosan. Water Research, 35, pp. 3904-3908, 2001. doi: http://dx.doi.org/10.1016/S0043-1354(01)00131-2

[11] Schintu, M., Meloni, P. \& Contu, A., Aluminium fractions in drinking water from reservoirs. Ecotoxicology and Environmental Safety, 46, pp. 29-33, 2000. doi: http://dx.doi.org/10.1006/eesa.1999.1887

[12] APHA. Standard Methods for the Examination of water and Wastewater, 20th edn. American Public Health Association, American Water Works Association, Water Environment Federation: Washington, DC, 1998. 
[13] Li, M., Zhu, X., Zhu, F., Ren, G., Cao, G. \& Song, L., Application of modified zeolite for ammonium removal from drinking water. Desalination, 271, pp. 295-300, 2011. doi: http:// dx.doi.org/10.1016/j.desal.2010.12.047

[14] Shen, Q., Zhu, J., Cheng, L., Zhang, J., Zhang, Z. \& Xu, X., Enhanced algae removal by drinking water treatment of chlorination coupled with coagulation. Desalination, 271, pp. 236-240, 2011.doi: http://dx.doi.org/10.1016/j.desal.2010.12.039

[15] Chatterjee, T., Chatterjee, S. \& Woo, S.H., Enhanced coagulation of bentonite particles in water by a modified chitosan biopolymers. Chemical Engineering Journal, 148, pp. 414-419, 2009. doi: http://dx.doi.org/10.1016/j.cej.2008.09.016

[16] Li, T., Zhu, Z., Wang, D., Yao, C. \& Tang, H., Characterization of floc size, strength and structure under various coagulation mechanisms. Powder Technology, 168, pp. 104-110, 2006. doi: http://dx.doi.org/10.1016/j.powtec.2006.07.003

[17] Yu, W.-Z., Liu, H.-J., Liu, T., Liu, R.-P. \& Qu, J.-H., Comparison of submerged coagulation and traditional coagulation on membrane fouling: effect of active flocs. Desalination, 309, pp. 11-17, 2013.doi: http://dx.doi.org/10.1016/j.desal.2012.08.012

[18] Wu, Y.-F., Liu, W., Gao, N.-Y.\& Tao, T., A study of titanium sulfata flocculation for water treatment. Water Research, 45, pp. 3704-3711, 2011. doi: http://dx.doi.org/10.1016/j.watres.2011.04.023

[19] ASTM, Standard Practice for Coagulation-Flocculation Jar Test of Water E1-1994 R(2008), D 2035-80. Annual Book of ASTM Standards, Vol. 11.02, ASTM International: West Conshohocken PA, 2008.

[20] Bose, P. \& Reckhow, D.A., The effect of ozonation on natural organic matter removal by alum coagulation. Water Research, 41, pp. 1516-1524, 2007. doi: http://dx.doi.org/10.1016/j.watres.2006.12.027

[21] Sharp, E.L., Parsons, S.A. \& Jefferson, B., Seasonal variations in natural organic matter and its impact on coagulation in water treatment. Science of the Total Environment, 363, pp. 183-194, 2006. doi: http://dx.doi.org/10.1016/j.scitotenv.2005.05.032

[22] Franceschi, M., Girou, A., Carro-Diaz, A.M., Maurette, M.T. \& Puech-Costes, E., Optimisation of the coagulation-flocculation process of raw water by optimal design method. Water Research, 36, pp. 3561-3572, 2002. doi: http://dx.doi.org/10.1016/S0043-1354(02)00066-0

[23] Konieczny, K., Sąkol, D., Płonka, J., Rajca, M. \& Bodzek, M., Coagulation - ultrafiltration system for river water treatment. Desalination, 240, pp. 151-159, 2009. doi: http://dx.doi. org/10.1016/j.desal.2007.11.072

[24] Li, G. \& Gregory, J., Flocculation and sedimentation of high turbidity waters. Water Research, 25, pp. 1137-1143, 1991. doi: http://dx.doi.org/10.1016/0043-1354(91)90207-7

[25] Li, M., Wu, G., Guan, Y. \& Zhang, X., Treatment of river water by a hybrid coagulation and ceramic membrane process. Desalination, 280, pp. 114-119, 2011. doi: http://dx.doi. org/10.1016/j.desal.2011.06.059

[26] Mukherjee, S., Bhattacharya, A.K. \& Mandal, S.N., Impact of aluminium based hydrolyzing coagulants and aids in river water clarification. WIT Transactions on Ecology and the Environment, 164, pp. 299-309, 2012.doi: http://dx.doi.org/10.2495/WP120261

[27] Martí, M., Policloruro de aluminio: un floculante innovador. Química 2000, 18, pp. 60-63, 1987.

[28] Harper, T. \& Rosenberg, A., Polyaluminium chloride: an alternative to conventional coagulants. World Water and Environmental Engineering, 28(4), pp. 9-15, 1995.

[29] Diamadopoulos, E. \& Vlachos, C., Coagulation - filtration of a secondary effluent by means of pre-hydrolyzed coagulants. Water Science Technology, 33(10-11), pp. 193-201, 1996. doi: http://dx.doi.org/10.1016/0273-1223(96)00420-9

[30] Letterman, R.D., AWWA Water Quality \& Treatment: A Handbook of Community Water Supplies, 5th edn. McGraw-Hill, Inc.: New York. 